\title{
Matéria
}

ISSN 1517-7076

\section{Comparative Study of Hydroxyapatite Coatings Obtained by Sol-Gel and Electrophoresis on Titanium Sheets}

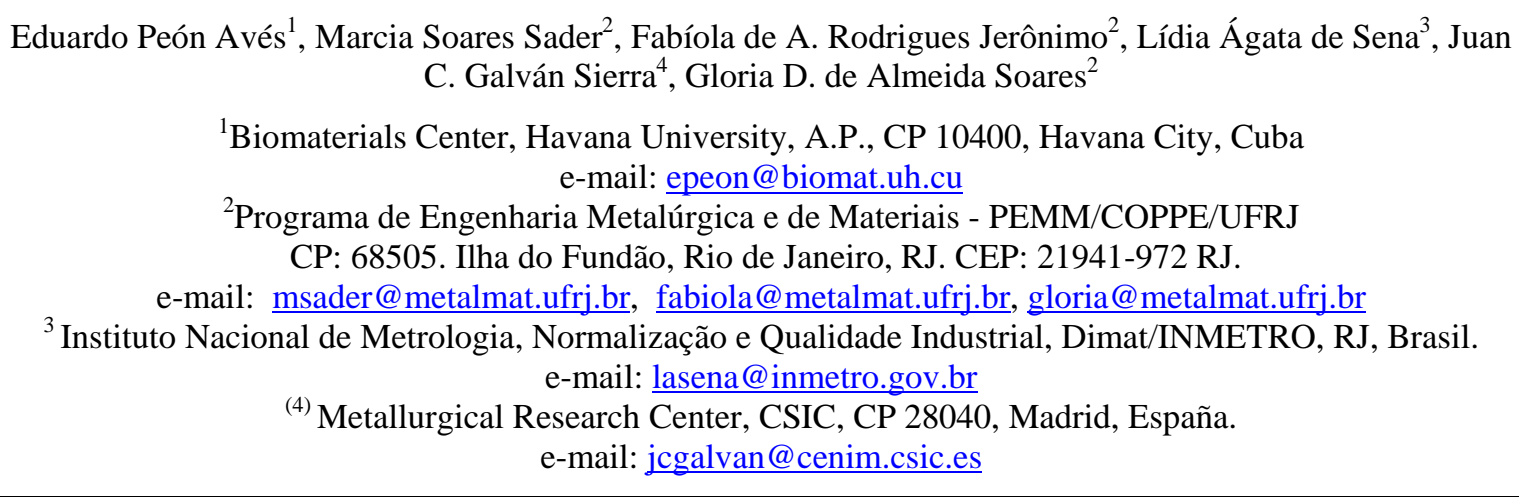

\section{ABSTRACT}

A comparative study of two coating methods on titanium (Ti) substrates, sol-gel and electrophoresis processes, was performed. Before coating, two different surface treatments were employed. The hydroxyapatite (HA) powder were characterized by infrared spectroscopy (FTIR) and X-ray diffraction (XRD) while coated samples were examined by using scanning electron microscopy (SEM) with energy dispersive spectroscopy (EDS). Both techniques seem to be suitable to coat Ti. A previous surface treatment on metallic titanium seems to be fundamental to enhance coat uniformity and adhesion that was estimated by the adhesive tape test. The decrease in calcination temperature did not affect the coating adhesion.

Keywords: Hydroxyapatite, Titanium, Sol-Gel, Electrophoresis

\section{INTRODUCTION}

Metallic biomaterials, such as titanium (Ti) and its alloys, are considered the best choice for manufacturing permanent implants due to their superior strength, low modulus and corrosion resistance in physiological environment. The high mechanical strength and toughness of these alloys are the most important advantages over bioactive hydroxyapatite (HA) ceramics. Therefore, a system that join both materials has the mechanical advantages of the underlying (metallic) substrate and biological affinity of the HA [11]. Coating metallic implants with bioactive materials, like HA, may accelerate bone formation on initial stages of osseointegration, improving implant fixation [12]. Thin HA film on Ti substrates can be prepared using sol-gel $[1,6,15]$ or electrophoresis $[10,13,14,17]$ techniques. The sol-gel and electrophoresis methods are capable of improving chemical homogeneity in the resulting HA coating to a significant extent, when compared to conventional methods such as solid state reactions, wet precipitation and hydrothermal synthesis $[\underline{7}, \underline{16}]$. These methods are also simple and less expensive than the plasma spraying method that is widely used for biomedical applications. The objective of this work was to coat Ti samples by two methods: a variant of the sol-gel process in water-based medium [ 5 ] and electrophoresis process [10]. A thermal treatment was used to improve coating crystallinity and adhesion $[4,8]$ and both coatings were characterized in terms of phase's composition and morphology.

\section{EXPERIMENTAL PROCEDURES}

Commercially pure Ti sheets of $10 \times 10 \mathrm{~mm}^{2}$ were used for this study. Two groups of samples were prepared. For the first group, Ti substrates were abraded on 400-grit silicon carbide (SiC), (P400, 3M) followed by a thermal treatment at $400^{\circ} \mathrm{C}$ to form a thick oxide layer to enhance coating adhesion (samples Ti400). For the second group, Ti sheets were submitted to mechanical blasting process with \#65 mesh alumina powder (Alumina Azul $\mathrm{n}^{\circ} 1, \mathrm{QM}$ ). The samples were etched with an acid solution containing hydrogen peroxide and hydrofluoric acid [3] to remove alumina $\left(\mathrm{Al}_{2} \mathrm{O}_{3}\right)$ particles and to produce a 
homogeneous rough surface (samples Ti65). All samples were ultrasonically cleaned in acetone for 15 min, alcohol for $10 \mathrm{~min}$, and water for $5 \mathrm{~min}$.

The sol-gel procedure has been detailed by D.M.Liu (2001) [5]. Briefly, triethyl phosphite (Aldrich) was first hydrolyzed for $24 \mathrm{~h}$ with a fixed amount of distilled water under vigorous stirring. A stoichiometric amount of calcium nitrate (Aldrich), 4M solution, was added into the hydrolyzed phosphite solution. Then, the resulting mixture was agitated for additional $30 \mathrm{~min}$ and aged for $24 \mathrm{~h}$. The coating on the metallic substrate with the sol-gel solution was prepared by spin-coating, with a speed of $4200 \mathrm{rpm}$ for 9 seconds.

For electrophoresis coating, the stoichiometric HA was prepared by wet precipitation [9]. HA suspension with $0,5 \mathrm{~g}$ of solid power in $100 \mathrm{~mL}$ of ethanol was prepared using hydrochloric acid as dispersing agent. The solution was rested for $1 \mathrm{~h}$ to allow the sedimentation of large HA particles [17]. An electrophoretic cell using titanium samples as cathode and platinum as anode was mounted, with electrodes 40mm apart applying 50V, 1 minute, to obtain a thin and uniform coating [10].

The powder obtained by sol-gel method and the HA used for electrophoretic coating were characterized by infrared spectroscopy (FTIR-ABB Bomem Inc., MB series) equipped with reflectance stage, recorded in the range of $400-4000 \mathrm{~cm}^{-1}$, and X-ray diffraction (XRD - D8, Focus, Brucker), performed with CuK $\alpha$ radiation $(30 \mathrm{KV}, 50 \mathrm{~mA})$. Data was acquired from $20-60^{\circ}(2 \theta)$.

The coatings produced by both techniques were submitted to a thermal treatment at $450^{\circ} \mathrm{C}$ for $5 \mathrm{~h}$ in vacuum in order to improve coating adherence. Four groups were then obtained, depending on the substrate treatment and coating process, as identified in Table 1. The morphologic characteristics and elementary composition of the HA coating obtained by the two processes was investigated by scanning electron microscopy (SEM-JEOL JSM-6460LV) with energy dispersive spectroscopy associated (EDS-Noran System Six 200). Coating adhesion was estimated using the adhesive tape test $[\underline{2}, \underline{10}]$ and coating was considered well adhered when no powder were retained on the tape's surface.

Table 1 - Identification of the coated samples

\begin{tabular}{|c|c|c|}
\hline Substrates & Sol-gel process & Electrophoresis process \\
\hline Ti ground with 400-grit $\mathrm{SiC}$ & Ti400SG & Ti400E \\
\hline Ti blasted with \#65 mesh $\mathrm{Al}_{2} \mathrm{O}_{3}$ & Ti65SG & Ti65E \\
\hline
\end{tabular}

\section{RESULTS AND DISCUSSION}

The distinct surface morphology of the two substrates used in this work can be observed in Fig 1 . Ti sheet previously blasted with alumina (Figure 1b) presented a rougher surface when compared with the ground one (Figure 1a).

The FTIR spectra of the powder obtained by sol-gel method and of the HA used on the electrophoresis coating are shown in Fig 2. The characteristic reflections of the vibrations $v_{4} \mathrm{PO}_{4}{ }^{3-}$ (at 563 , 600 and $942 \mathrm{~cm}^{-1}$ ), $v_{1} \mathrm{PO}_{4}{ }^{3-}$ (at $1000 \mathrm{~cm}^{-1}$ ) and $v_{3} \mathrm{PO}_{4}^{3-}$ (at $1100 \mathrm{~cm}^{-1}$ ) were observed for both coatings. These reflections indicate the reordering of the polyhedrons of $\mathrm{PO}_{4}{ }^{3-}$ in the structure of the crystal. The band at 631 $\mathrm{cm}^{-1}$ and the sharp band at $3570 \mathrm{~cm}^{-1}$ are characteristic for the apatite structure and are attributed to the vibration of $\mathrm{OH}^{-}$groups. The broad band ranging from 3300 and $3600 \mathrm{~cm}^{-1}$ can be explained owing to $\mathrm{O}-\mathrm{H}$ group stretch vibration of absorbed water. In the powder obtained by sol-gel process the $\mathrm{CO}_{3}{ }^{2-}$ incorporation was detected by the presence of the bands at $870 \mathrm{~cm}^{-1}\left(v_{2} \mathrm{CO}_{3}{ }^{2-}\right), 1422$ and $1460 \mathrm{~cm}^{-1}\left(v_{3} \mathrm{CO}_{3}{ }^{2-}\right)$. The characteristic peak of $\mathrm{CO}_{3}{ }^{2-}$ on electrophoresis coating is less intense. 


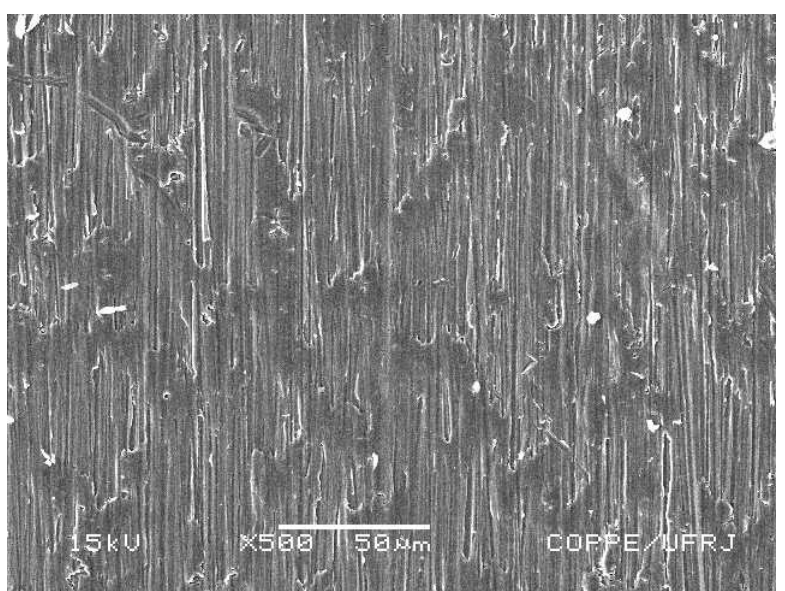

(a)

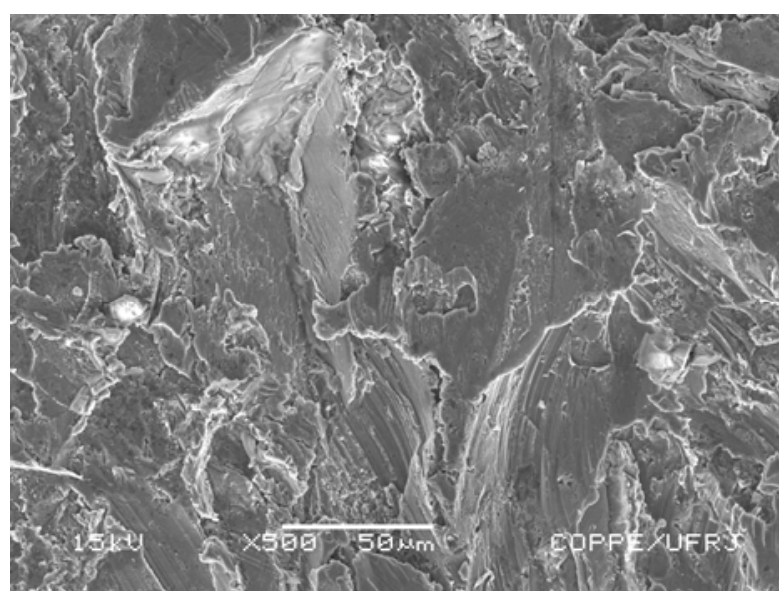

(b)

Figure 1- SEM micrographs of the substrate surfaces: (a) Ti ground with SiC 400 (Ti400) and (b) Ti blasted with $\mathrm{Al}_{2} \mathrm{O}_{3} \# 65$ (Ti65)

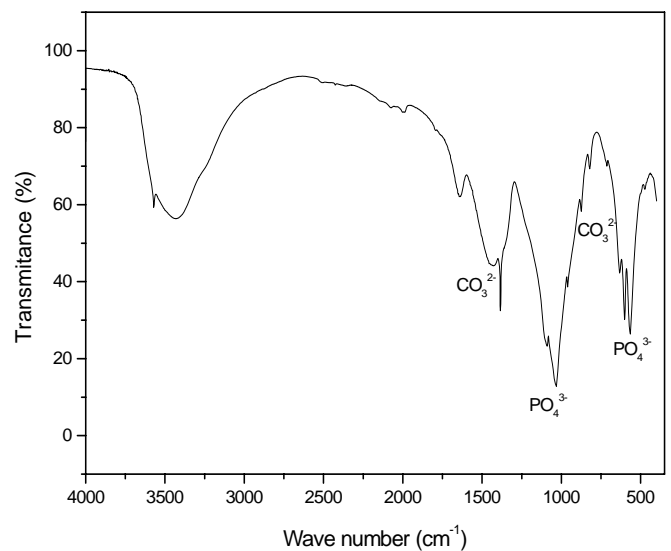

(a)

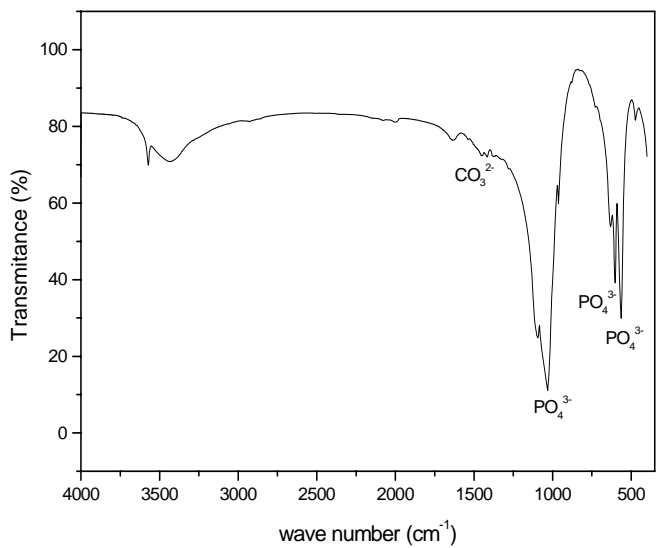

(b)

Figure 2- FTIR spectra of the powder used on sol-gel (a) and electrophoresis methods (b)

The XRD patterns of the powder obtained by sol-gel method and of the HA used on the electrophoresis coating are shown in Figure 3. Both patterns were assigned to hydroxyapatite, according to the JCPDS 9-432 card. The powder used on electrophoresis procedure is slight less crystalline than sol-gel powder. As after coating, alls sheets were thermal treated, the final cristallinity should be similar. 


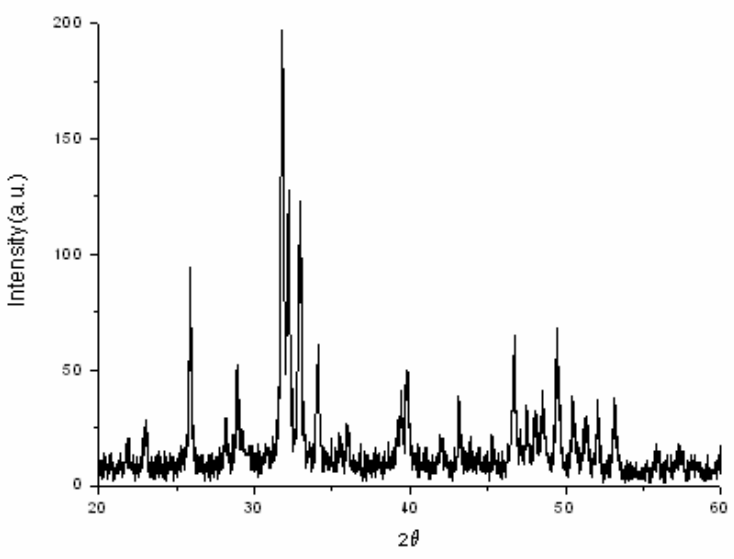

(a)

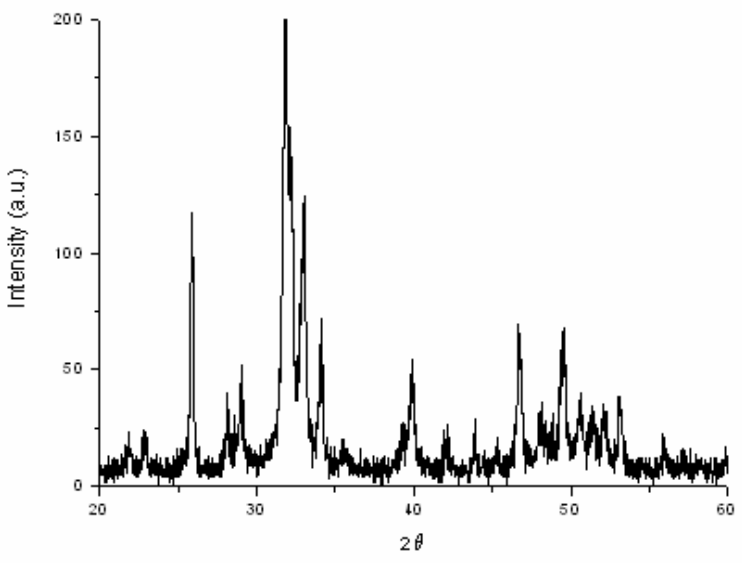

(b)

Figure 3- XRD patterns of the powder used on sol-gel (a) and electrophoresis methods (b).

Figures 4 to 7 show the morphology of the coatings investigated by SEM-EDS. A significant difference in the microstructure of the coating obtained by the two processes can be noted, although a dense HA layer can be obtained for both methods. However, in some cases we can see some discontinuity on the coatings, with the sol-gel coatings being less uniform than the electrophoresis ones.

The HA coatings obtained by sol-gel processes on the ground sample (Ti400SG), Figure 4a, were not homogeneous, exposing the Ti substrate. This was confirmed by EDS analysis, Figure 4 b-d, were the bright regions correspond to the Ti surface.

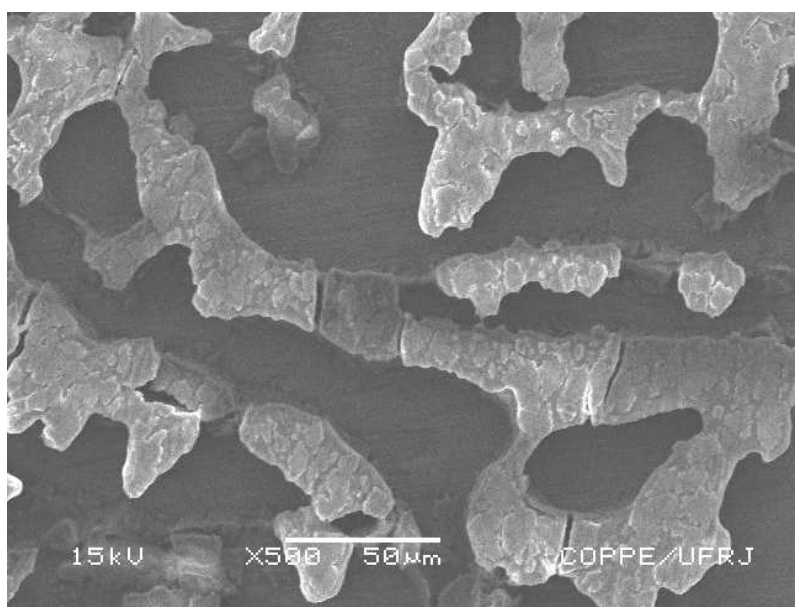

(a)

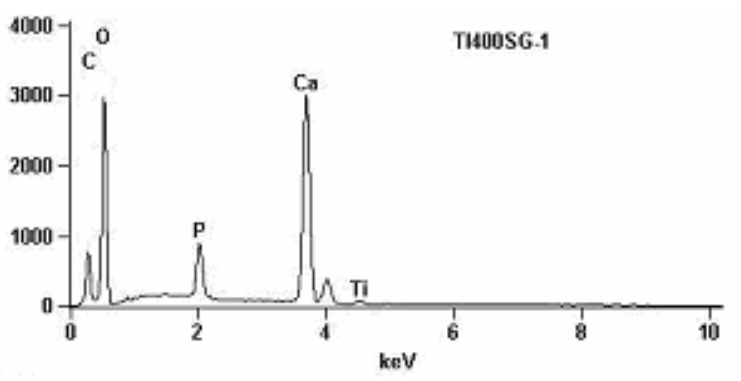

(c)

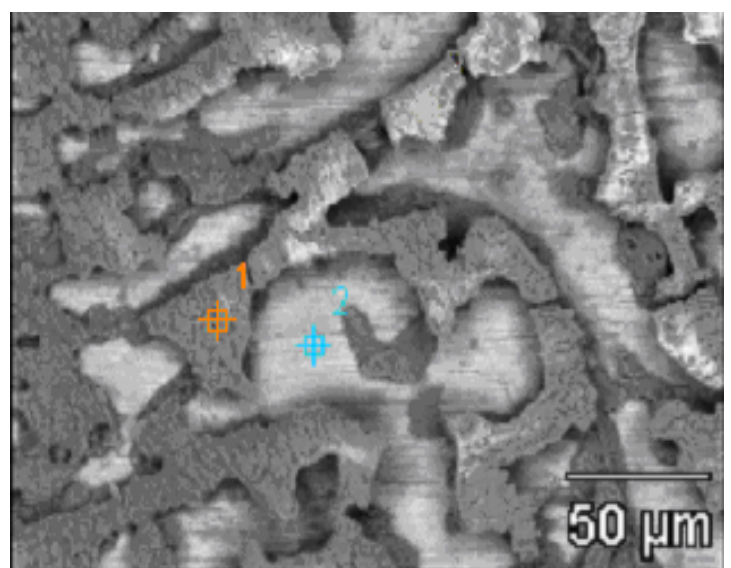

(b)

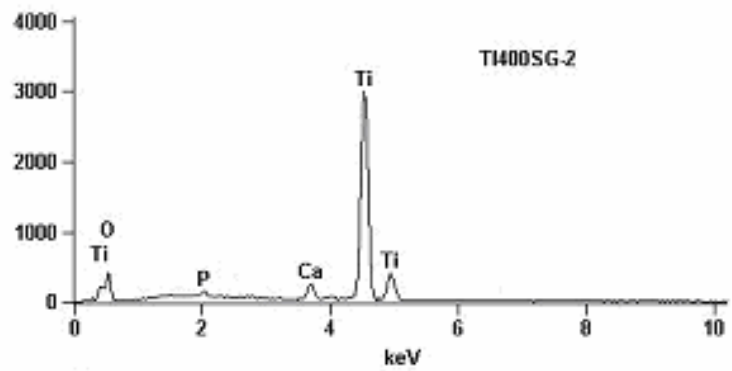

(d) 
Figure 4- SEM micrograph of HA coating obtained by sol-gel procedure on Ti400SG sample (a) and EDS spectra (c) and (d) of area showed on (b)

For the samples blasted with $\mathrm{Al}_{2} \mathrm{O}_{3}$ (Ti65SG), Figure 5, the Ti area exposed was less visible (Figure 5a). The presence of calcium and phosphorous on the deposits was observed on the EDS spectrum, Figure 5d, although there were still minor areas not coated (corresponding to spectrum with high Ti peaks, Figure 5c). The surface treatment applied to the substrates play an important role in the resulting coating uniformity. The blast plus acid treatment on the $\mathrm{Ti}$ substrate creates a homogeneous rough microtopography, increasing the samples' surface area. It seems to act as anchorage points for the coating [10]. On Ti65SG substrate, coating adhesion—inferred throughout the adhesive tape test—was much higher than for ground sample.

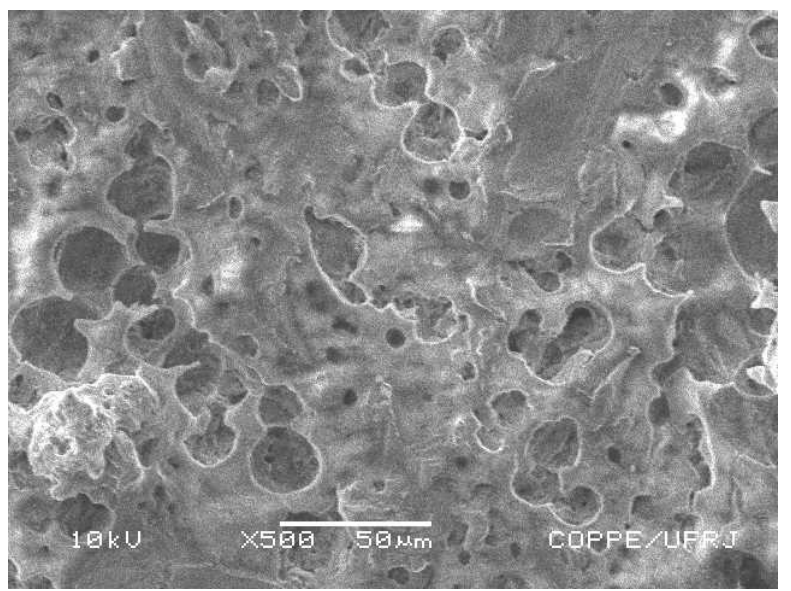

(a)

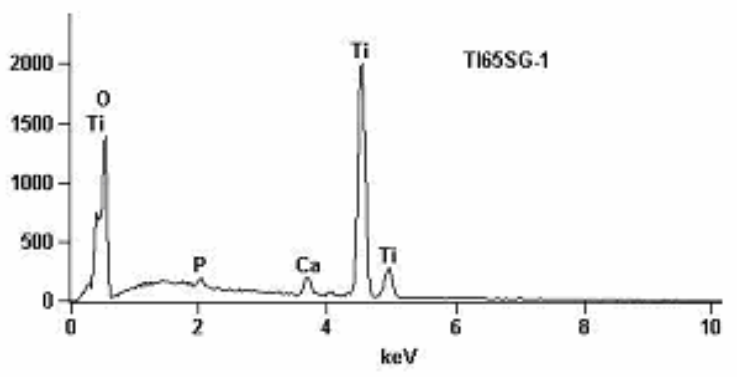

(c)

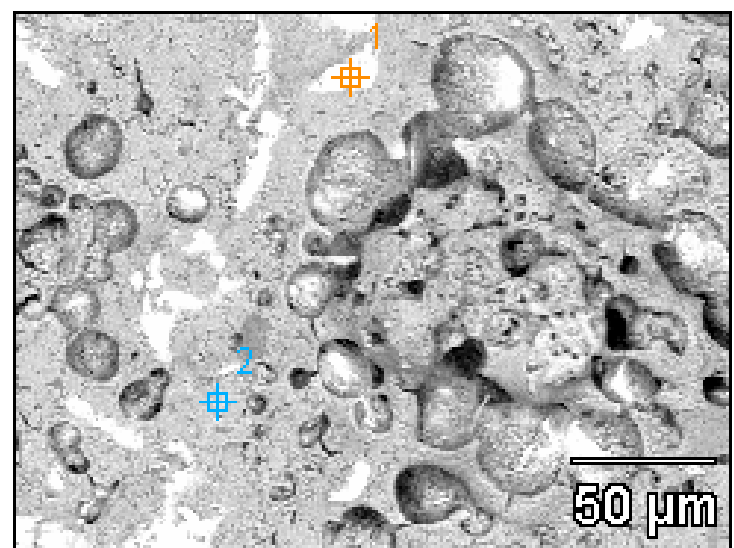

(b)

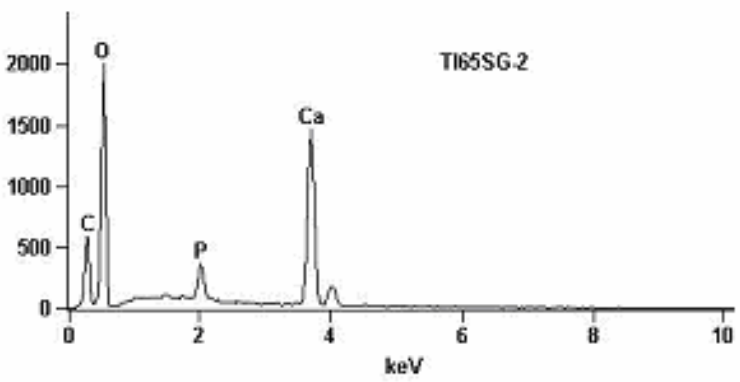

(d)

Figure 5- SEM micrograph of HA coating obtained by sol-gel procedure on Ti65SG sample (a) and EDS spectra (c) and (d) of area showed on (b)

In low magnification (not shown) the coating by electrophoresis method exhibit better uniformity than the sol-gel coating for both substrates. The effect of the substrates (Ti400E and Ti65E) in the deposit's morphology can be observed in Figure 6a and 7a, respectively. By the tape test method, the rough surface result in a well adhered coating. EDS analysis of HA coating by electrophoresis procedure on both Ti substrates can be observed on Figure 6b-d and 7b-d, respectively. On both substrates some exposed area can be observed. The reduction of calcination temperature from 800 [10] to $450^{\circ} \mathrm{C}$ (herein) did not alter the HA layer adhesion, when inferred throughout the adhesive tape test. Moreover, low temperatures of heat treatment is more convenient to preserve the mechanical properties of metallic titanium. 


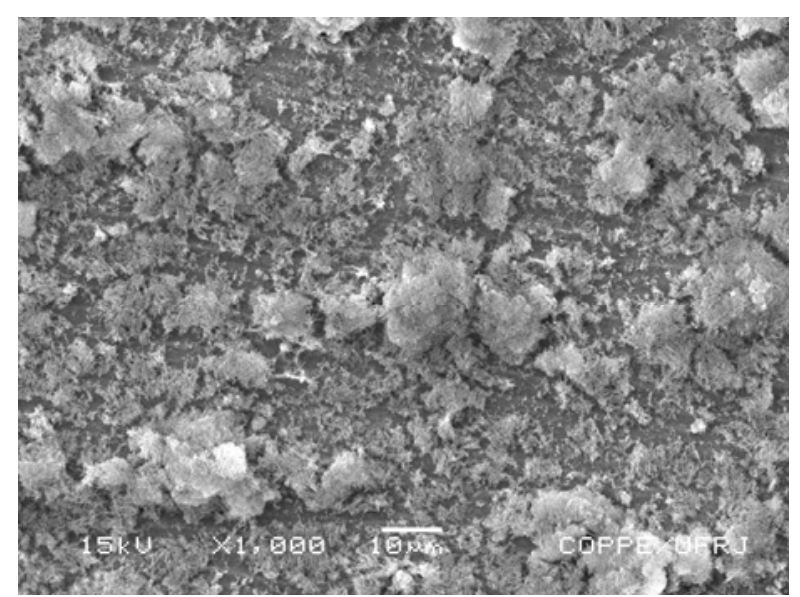

(a)

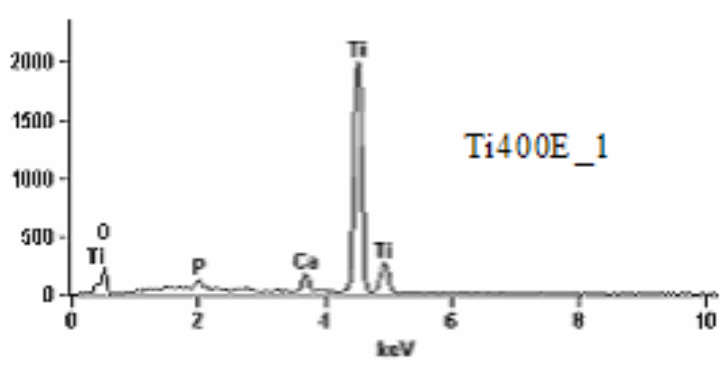

(c)

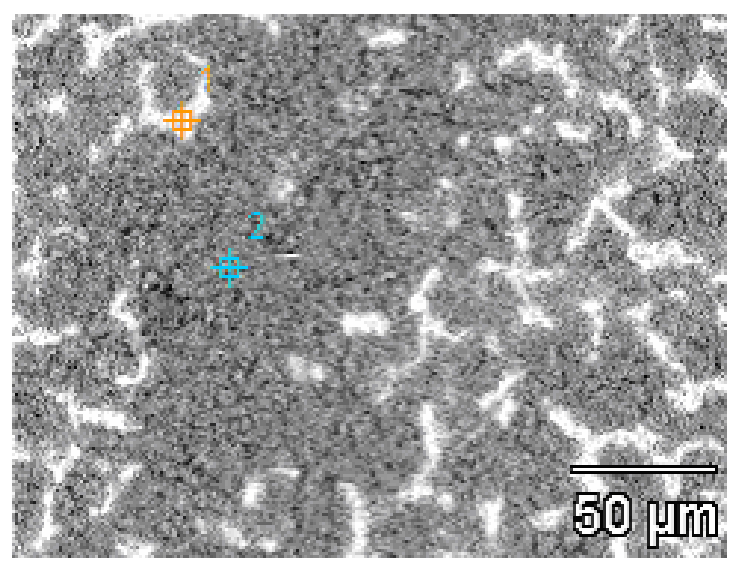

(b)

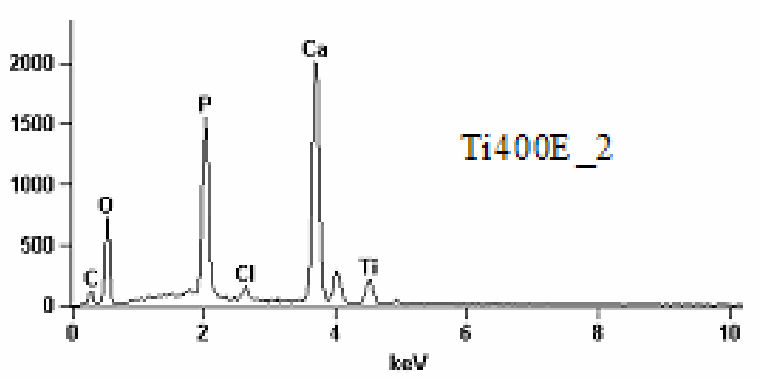

(d)

Figure 6- SEM micrograph of HA coating obtained by electrophoresis procedure on Ti400E sample (a) and EDS spectra (c) and (d) of area showed on (b)

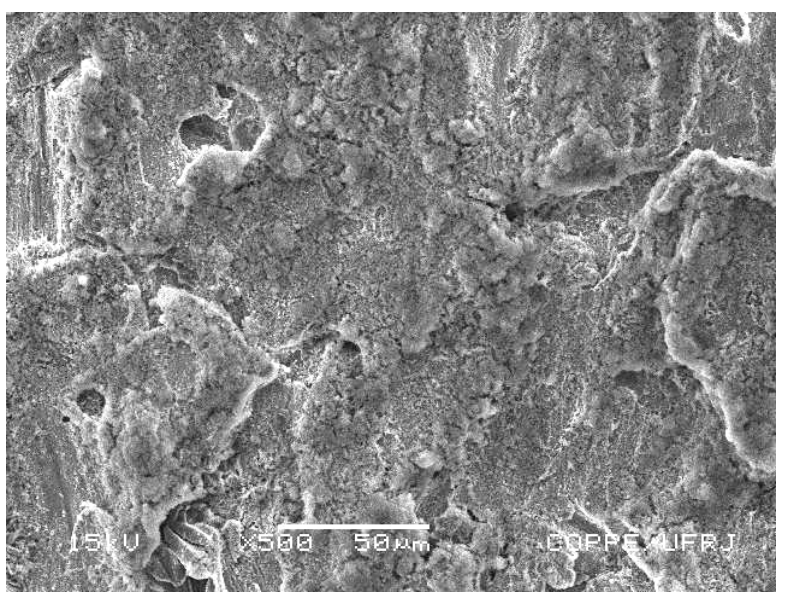

(a)

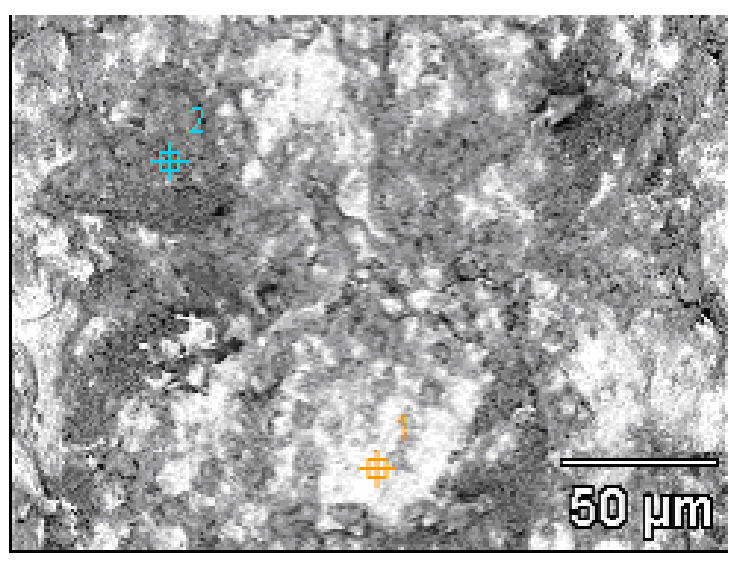

(b) 


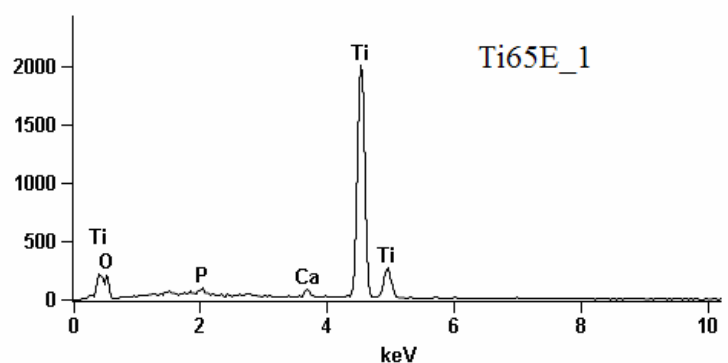

(c)

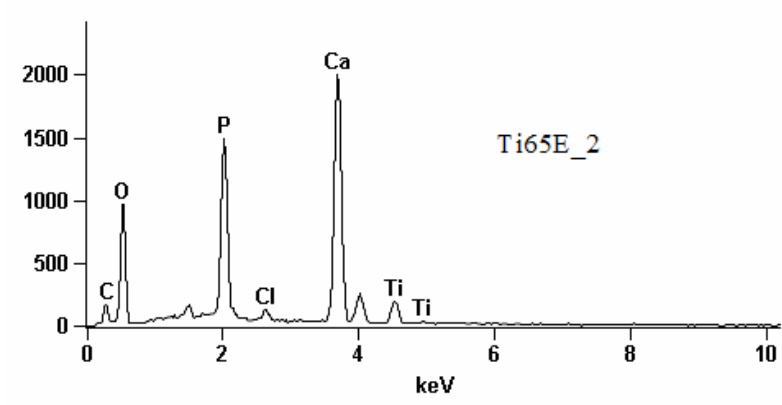

(d)

Figure 7- SEM micrograph of HA coating obtained by electrophoresis procedure on Ti65E sample

(a) and EDS spectra (c) and (d) of area showed on (b)

\section{CONCLUSIONS}

Both techniques, sol-gel and electrophoresis, are suitable to coat metals and similar results on titanium sheets were obtained. A previous surface treatment on metallic titanium seems to be fundamental to enhance coat uniformity and adhesion. The decrease in calcination temperature did not affect the coating adhesion, estimated by the adhesive tape test.

\section{ACKNOWLEDGEMENTS}

The authors thank the financial support of CAPES, CNPq, FAPERJ, and the cooperative project between $\mathrm{CNPq} /$ Brasil and MES/Cuba. They also thank the Inorganic Chemistry Department/IQ//UFRJ for infrared spectroscopy.

\section{REFERENCES}

[1] BOGDANOVICIENE, I., BEGANSKIENE A., TONSUAADU K., GLASER, J., MEYER, H. J., KAREIVA A., "Calcium Hydroxyapatite $\left(\mathrm{Ca}_{10}\left(\mathrm{PO}_{4}\right)_{6}(\mathrm{OH})_{2}, \mathrm{HA}\right)$ Ceramics Prepared Through Aqueous sol-gel processing”, Materials Research Bulletin, v. 41, pp. 1754-1762, 2006.

[2] DE ANDRADE, M.C., SADER, M.S., FILGUEIRAS, M.R.T., OGASAWARA, T., "Microstruture of Ceramic Coating on Titanium Surface as a Result of Hydrothermal Treatment", Journal of Materials Science: Materials in Medicine, v. 11, pp. 751-755, 2000.

[3] DINIZ, M.G., SADER, M.S., SOARES, G.A., "Superfície de Titânio Modificada por Jateamento Mecânico e/ou Tratamento Ácido”, Brazilian Dental Mag Ver. RBO, v. 58, pp. 135-138, 2001.

[4] HWANGA. K.E., KIM, C.S., "Interface Characteristics Changed by heat Treatment of Ti Materials with Hydroxyapatite”, Materials Science and Engineering, v. C23, pp. 401-405, 2003.

[5] LIU, D.M., TROCZYNSKI, T., TSENG, W.J., "Water-based sol-gel Synthesis of Hydroxyapatite: Process Development”, Biomaterials, v. 22, pp. 1721-1730, 2001.

[6] MANSO-SILVA, M., LANGLETB, M., JIMENEZ, C., FERNANDEZ, M., MARTINEZ-DUARTA, J.M., "Calcium phosphate coatings prepared by aerosol-gel", Journal of the European Ceramic Society, v. 23, pp. 243-246, 2003.

[7] MILEV, A., KANNANGARA, G.S.K., BEN-NISSAN, B., "Morphological Stability of Hydroxyapatite Precursor”, Materials Letters, v. 57, pp. 1960-1965, 2003.

[8] PEON, E., MORALES, A.J., ESCALANTE, E.F., GALVÁN, J.C., ALONSO, M.C.G., ESCUDERO, M.L., "Hydroxyapatite Coatings Prepared by a sol-gel Process", Revista de Metalurgia Madrid, v. Extr., 2005. 
[9] ROSSI, A.M., LIMA, E.M., MOURA, T., SOARES, G.A., PEREZ, C.A.C., "Textural and Surface Properties of Hydroxyapatite Synthesized in Different Conditions”, Key Engineering Materials, v. 192-195, pp. 275-278, 2001.

[10] SENA, L.A., ANDRADE, M.C., ROSSI, A.M., SOARES, G.A., "Hydroxyapatite Deposition by Electrophoresis on Titanium Sheets with Different Surface Finishing”, Journal of Biomedical Materials Research, v. 60, pp. 1-7, 2002.

[11] SUROWSKA, B., BIENIAS, J., WALCZAK, M., SANGWAL, K., STOCH, A., "Microstructure and Mechanical Properties of Ceramic Coatings on Ti and Ti-based Alloy”, Applied Surface Science, v. 238, pp. 288-294, 2004.

[12] VIDIGAL JR., G. M., ARAGONES, L.C.A., CAMPOS, A.JR., GROISMAN, M., "Histomorphometric Analyses of hydroxyapatite-coated and Uncoated Titanium Dental Implants in Rabbit Cortical Bone”, Implant Dent, v. 8, pp. 295-302, 1999.

[13] WANG, C.M.J., CHENG, W., ZHANG, R., “Thick Hydroxyapatite Coatings by Electrophoretic Deposition”, Materials Letters, v. 57, pp. 99- 105, 2002.

[14] XIAO, X.F., LIU, R.F., "Effect of Suspension Stability on Electrophoretic Deposition of Hydroxyapatite Coatings”, Materials Letters, v. 60, pp. 2627-2632, 2006.

[15] XU, W., HU, W., LI, M., WEN, C., “Sol-gel Derived hydroxyapatite/titania Biocoatings on Titanium Substrate”, Materials Letters, v. 60, pp. 1575-1578, 2006.

[16] YANG, B., UCHIDA, M., KIM, H.M., ZHANG, X., KOKUBO, T., "Preparation of Bioactive Titanium Metal via Anodic Oxidation Treatment”, Biomaterials, v. 25, pp. 1003-1010, 2004.

[17] ZHITOMIRSKY, I., GAL-OR, L., “Electrophoretic Deposition of Hydroxyapatite”, Journal of Material Science: Materials in Medicine, v. 8, pp. 213-219, 1997. 